\title{
THE USE OF A PROJECTIVE TECHNIQUE TO INVESTIGATE THE INTENTION OF KINDERGARTEN STUDENTS IN USING A TABLET PC
}

\author{
Usep Suhud, Sofia Hartati dan Widya Pramesti \\ e-mail: usuhud@unj.ac.id \\ Faculty of Economics, Universitas Negeri Jakarta, Indonesia
}

\begin{abstract}
This study aims to measure the impact of social influence on performance expectation, motivation, and attitude, and its implication on intention of kindergarten students to adopt a Tablet PC. In this study, a projective technique was employed. The projective technique is a method used by participants to measure third persons' behavior. Data was collected in March-April 2016 in Jakarta, involving 210 kindergarten students' parents. Data was analyzed using an exploratory and structural equation model. Based on the calculation, the Tablet PC adoption intention is affected by performance expectation while performance expectation is affected by social influence. Furthermore, adoption intention is also affected by attitude towards adoption. Recommendations for educators, practitioners, and future study are discussed.
\end{abstract}

Keywords: Tablet PC, projective technique, kindergarten students, social influence, performance expectance, adoption intention

\section{PENGGUNAAN TEKNIK PROYEKTIF UNTUK MENGIDENTIFIKASI NIAT SISWA TK DALAM MENGGUNAKAN TABLET PC}

\begin{abstract}
Abstrak: Penelitian ini bertujuan untuk mengukur dampak pengaruh sosial terhadap harapan kinerja, motivasi, dan sikap, dan implikasinya terhadap niat siswa TK untuk mengadopsi Tablet PC. Dalam penelitian ini, teknik projektif digunakan. Teknik projektif adalah metode sampling dengan menggunakan responden untuk mengukur perilaku orang ketiga. Data dikumpulkan pada bulan Maret-April 2016 di Jakarta, yang melibatkan 201 orang tua siswa TK. Data dianalisis dengan menggunakan model eksploratori analisis faktor (exploratory factor analysis) dan structural equation model. Berdasarkan perhitungan tersebut, niat adopsi PC tablet dipengaruhi oleh ekspektasi kinerja sedangkan ekspektasi kinerja dipengaruhi oleh pengaruh sosial. Selanjutnya, niat adopsi juga dipengaruhi oleh sikap terhadap adopsi. Rekomendasi untuk pendidik, praktisi, dan studi masa depan dibahas.
\end{abstract}

Kata-kata kunci: Tablet PC, teknik proyektif, siswa taman kanak-kanak, pengaruh sosial, harapan kinerja, niat adopsi

\section{INTRODUCTION}

M-learning has been promoted in all level of education institutions, including primary schools (Deursen, Allouch, \& Ruijter, 2016), secondary schools (Mäkitalo-Siegl, 2013), and higher education (El-Gayar, Moran, \& Hawkes, 2011). To conduct an m-learning, devices are required as a medium. The types of media include handhelds, laptop, tablet PC, cell phone, iPod or MP3 player, e-book reader, digital pen, pocket dictionary, and classroom response systems (Sung, Chang, \& Liu, 2016). According to Vanwelsenaers (2012), m-learning technology (smart phones, touch screen tablets) will motivate students to learn, enhance the learning experience, and improve student learning in classrooms. In this study, the authors focus on predicting the intention of kindergarten students to adopt a technology device, particularly a tablet PC.

A person's behavioural intention to use a tablet PC has widely studied by researchers. Two prominent theories to predict a person's intention and behaviour relating to technology acceptance are technology acceptance model (TAM) (Davis, Bagozzi, \& Warshaw, 1989) and unified theory of acceptance and use of technology (UTAUT) 
(Venkatesh, Morris, Davis, \& Davis, 2003). While Davis et al. (1989) included perceived ease of use, perceived usefulness variables, and attitude towards behaviour in their model, Venkatesh et al. (2003) employed variables: performance expectancy, effort expectancy, social influence, and facilitating conditions as predictors variables. Other scholars combined both of these theories, for example ElGayar et al. (2011). However, in this current study the authors employ social influence, motivation, attitude, and performance expectation as predictor variables.

Existing literature demonstrate that a PC tablet or other devices adoption intention can be affected by various variables. For example, attitude, subjective norm, perceived behavioural control, motivation, social influence, performance expectation, perceived usefulness, self-efficacy, perceived ease of use, perceived financial resources, perceived risk, innovation resistance, lifestyle media sceptic, effort expectancy, anxiety, technology ownership, innovation attributes, media use, and demographic profiles (Ifenthaler \& Schweinbenz, 2013; Lee, 2014; Lee, 2013; Li, 2014; Lu \& Viehland, 2008; Moran, Hawkes, \& El Gayar, 2010).

This study aims to measure the impact of social influence on motivation, attitude, and performance expectation and its implication on behavioural intention to use a tablet PC. Although the use of tablet PC has been gleaned by many researchers, however, there is lack of scholarly attention focussing on kindergarten students. In term of method, the application of a projective technique also makes this study different with existing studies. Social influence, performance expectation, and behavioural intention

Social influenced is defined as "change in an individual's thoughts, feelings, attitudes, or behaviours that results from interaction with another individual or a group" (Rashotte, 2007, p. 4426). Prior studies found a significant impact of social influence on performance expectation and behavioural intention (El-Gayar \& Moran, 2006; El-Gayar et al., 2011; Magsamen-Conrad, Upadhyaya, Joa, \& Dowd, 2015). In this current study, social influence is linked to performance expectation and tablet PC adoption intention.

The use of computer in such higher education institutions is mandatory. El-Gayar and Moran (2006) measured the behavioural intention of college and university students to adopt a technology-based initiative. These scholars used and found that performance expectancy, effort expectancy, social influence, self efficacy, attitude towards using technology, and anxiety significantly impacted intention.

Furthermore, El-Gayar et al. (2011) showed another document explaining that social influence had a significant impact on performance expectation and adoption intention among college students. Two of their findings were that social influence affected performance expectation and adoption intention.

Other scholars, such as Magsamen-Conrad et al. (2015), Riaz and Adnan (2016), Thomas, Singh, and Gaffar (2013) and Tosuntaş, Karadağ, and Orhan (2015) showed that social influence and performance expectancy had a significant impact on adoption intention.

H1 - Social influence will significantly affect performance expectation

H2 - Social influence will significantly affect use intention

H3-Performance expectation will significantly affect use intention

Attitude towards technological adoption and behavioural intention

Attitude represents a person's feeling whether positive or negative, like or dislike towards something or someone (Breckler, Olson, \& Wiggins, 2005; Gilbert, 2015). Regarding performance expectation of a tablet PC, Dündar and Akçayır (2014) studied high school students in Turkey. They revealed that a tablet PC should have office programs (Word, Excel, and PowerPoint), dictionary (English-Turkish), more durable batteries, other feature such as USB port, VGA output, etc., and an easy facility to transfer files to tablet PCs (story, novel, music, photograph, etc.).

Using a qualitative approach, Ifenthaler and Schweinbenz (2013) studied the intention of teachers to use a tablet PC. They depicted roles of attitude and performance expectancy. Another qualitative approach was used by Cuhadar (2014). This scholar explored attitudes of pre-service teachers towards intention to use a tablet PC. According to this scholar, attitude led to an intention.

Foon (2014) surveyed students of public and private universities in Malaysia. This scholar found that attitude and performance expectation had a significant impact on intention to use a tablet PC to replace a textbook. Some other scholars (AbuAl-Aish \& Love, 2013; Astuti, Zentira, \& Dwiantoro, 
2016; El-Gayar et al., 2011; Moran et al., 2010) have tested that idea and documented a significant impact of attitude and performance expectancy on intention, particularly on the use of a tablet PC.

Other approaches to measure behavioural intention relating to the adoption of modern technology-based devices are by employing and/ adapting the theory of planned behaviour (TPB) and technology acceptance model (TAM). In those theories, attitude is one of the predicting variables to predict adoption intention. For example, Aboelmaged and Gebba (2013) and Teo and Pok (2003) selected TPB. Furthermore, Bruner and Kumar (2005), ElGayar and Moran (2007), Park and Pobil (2013), and Wu, Wang, and Lin (2007) applied TAM. Together, these scholars found a significant impact of attitude on intention.

H4 - Attitude toward use will significantly affect use intention

\section{Motivation and behavioural intention}

According to Mirusmonov and Kim (2013), motivation consists of intrinsic and extrinsic motivation. They measured intrinsic motivation using self-efficacy, familiarity, and affinity whereas to measure extrinsic motivation, they used reputation, social interaction, and technology interactivity. In this study, motivation is linked to adoption intention.

Chang, Liang, Yan, and Tseng (2013) applied the idea of distinguishing motivation into intrinsic and extrinsic. They found that these variables significantly influenced the intention of students to adopt a technology.

Fagan, Neill, and Wooldridge (2008) tested the intention of managers of mid-sized manufacturing in North America to use computers. They linked intrinsic motivation to extrinsic motivation and linked extrinsic motivation to behavioural intention. These scholars considered these two motivation variables as two sequential paths. They found that intrinsic motivation significantly influenced extrinsic motivation, and extrinsic motivation significantly influenced behavioural intention. The same approach but in different direction was employed by Yoo, Han, and Huang (2012) in testing the intention of employees in Korea in using e-learning in the workplace. They linked extrinsic motivation to intrinsic motivation and behavioural intention, and intrinsic motivation was linked to behavioural intention. As a result, while extrinsic motivation on intrinsic motivation and intrinsic motivation on intention were significant, extrinsic on intention was insignificant.

Saadé, Tan, and Nebebe (2008) compared acceptance of a web-based learning system among students in China and Canada. One of the hypotheses they examined was the impact of intrinsic motivation on behavioural intention. As a result, the intention of both students in China and Canada were significantly influenced by intrinsic motivation. The same approach was also adopted by Abduljalil and Zainuddin (2015) and resulted the same finding.

Differently, Venkatesh, Thong, and Xu (2012) added hedonic motivation into the model they tested. The idea of using hedonic motivation in predicting behavioural intention was followed by Kim, Kim, and Wachter (2013). They even added another two forms of motivations: utilitarian and social motivations. Both these studies reported that in general, motivation had a significant influence on intention. Although prior studies tented to treat motivation as two different variables: intrinsic or extrinsic motivation, intrinsic and extrinsic motivations, or hedonism motivation, in this study however, the authors treat motivation as a single variable.

H5 - Motivation will significantly affect use intention Theoretical framework

Based on the literature review presented above, here is the theoretical framework to be tested. This framework is addressed to predict the impact of social influence, performance expectation, attitude towards adoption, and motivation on intention to adopt a tablet PC. This framework consists of five hypotheses.

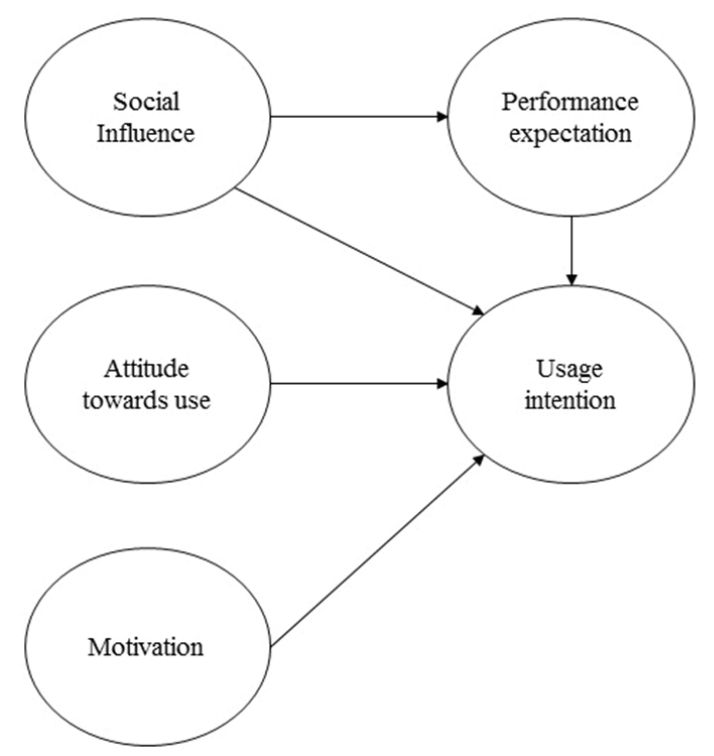

Figure 1. The theoretical framework 


\section{RESEARCH METHODOLOGY}

\section{Sample}

Participants were parents who were approached conveniently around several kindergartens in Jakarta. In Indonesia, most kindergartens start at 7.30 and end at 10.30 from Monday to Friday. Parents, older people from the family, or baby sitters commonly stay at schools waiting their child. Those who lived surrounding the school would go home and come back to school when the time out approaching. The questionnaires were distributed within those periods of time and self-administered between March and April 2017. The parents were asked to be a proxy of their kids. In the methodological practice it is called as projective sampling technique (Steinman, 2008).

\section{Measures}

In total, there are five variables included in this study. Each variable is measured using items taken and adapted from existing literature. Social influence is measured by items from Akbar (2013) and O'Regan and Chang (2015). For measuring performance expectation, items from H.-N. Sung, Jeong, Jeong, and Shin (2015) and Yang and Forney (2013) are adopted. Furthermore, for measuring attitude towards adoption, items from El-Gayar et al. (2011), O'Regan and Chang (2015), and H.-N. Sung et al. (2015). Additionally, items from Escobar-
Rodríguez, Carvajal-Trujillo, and Monge-Lozano (2014) and Kim et al. (2013) are used to measure motivation. Finally, items from Hassan, Kouser, Abbas, and Azeem (2014) and O'Regan and Chang (2015) are adapted to measure adoption intention.

\section{Data analysis}

Data was analysed in four steps. Firstly, the authors conducted exploratory factor analysis (EFA) to seek dimensions if any and keep only items with factor loadings of 0.4 and greater (Hair Jr., Black, Babin, Anderson, \& Tatham, 2006). This action is followed by conducting a reliability test for each factor established by EFA calculation. The authors choose only factors with a Cronbach's alpha score of 0.7 and greater to be included for further analysis (Hair Jr. et al., 2006).

Secondly is to conduct confirmatory factor analysis (CFA) with a purpose to obtain a fitted construction among factors tested. The last step is to conduct structural equation model (SEM) for testing the proposed research framework. A fitted model will be considered if this has a probability score of 0.05 (Schermelleh-Engel, Moosbrugger, \& Müller, 2003), CMIN/DF score of $\leq 2$ (Tabachnick \& Fidell, 2007), CFI score of $\geq 0.97$ (Hu \& Bentler, 1995), and RMSEA score of $\leq 0.05$ (Hu \& Bentler, 1999).

\section{FINDINGS AND DISCUSSION}

\section{Participants}

As indicated by participants, $130(64.7 \%)$ of their children were at the first year of a kindergarten, 60 participants $(29.9 \%)$ were at the second year of a kindergarten, and 11 participants $(5.5 \%)$ were at a playgroup. In total, there were 201 participants taking part of this study, consisting of 114 males (56.7\%) and 87 females (43.3). Thirty-four participants were in the age of $20-24$ years old ( $16.9 \%)$, followed by 66 participants were in the age of 25-29 years old $(32.8 \%)$. Additionally, 54 participants were in the age of $30-34$ years old (26.9\%), and 41 participants were in the age of 35-39 years old. The remaining participants were 40 years old and older.

All these participants declared that they had one or more children and $174(86.6 \%)$ of them mentioned that they had a tablet. Those who did not have a tablet PC, 32 of them (15.9\%) had a plan to buy a tablet PC within three months ahead, 12 of them $(6 \%)$ had a plan to buy within six months ahead, and 13 of them $(6.5 \%)$ had a plan to buy a tablet PC within a year ahead.

As this is a projective technique, participants claimed that they filled out the questionnaire on behalf of the first kid $(149=74.1 \%)$, second kid (43= $21.4 \%)$, and third kid $(9=4.5 \%)$. Regarding the age of the kids, 71 participants had a kid of six years old (35.3\%), 55 participants with a kid of five years ole (27.4\%), 46 participants with a kid of four years old $(22.9 \%)$, and the remaining participants have a kid younger than four years old.

Most participants claimed that they possessed a tablet PC (150). Predominantly, the brand name of tablet PC they owned was Samsung (68), followed by Advan (40), Apple (16), and others - Lenovo, Asus, Evercross, Smartfren, Axio, Polytron, Mito, 
Oppo, and HP. Those who had a tablet PC, they lent the tablet to their children (130), bought one for their children (60), borrowed from their children (7), and their children borrowed from their friends (15).

When the participants were asked about the duration their children using a tablet $\mathrm{PC}, 73$ participants indicated 1-2 hours/day and 31 of them said 2-4 hours/day. Predominantly, 84 participants said that they were not sure about the length of their children playing with the tablet PC.

\section{Exploratory Factor Analysis}

In this section, the authors present EFA results. Items of each variable was calculated individually. The results are presented in tables below. Each table has columns consisting of codes of items, adapted items in English, and adapted items tested in Bahasa Indonesia.

\section{Social Influence}

Four items of social influence retain. This construct has factor loadings ranging from 0.769 to 0.820 and a Cronbach's alpha score of 0.815 .

Table 1

EFA Result of Social Influence

\begin{tabular}{cll}
\hline \multicolumn{1}{c}{ Items } & $\alpha=0.815$ \\
\hline SI3 & $\begin{array}{l}\text { Teachers at the school will help my kid to } \\
\text { play while studying through a tablet PC }\end{array}$ & 0.820 \\
SI1 & $\begin{array}{l}\text { My family thinks that my kid will be better off } \\
\text { playing using a tablet PC in his/her spare time }\end{array}$ & 0.818 \\
SI4 & $\begin{array}{l}\text { The kindergarten where my kid studies } \\
\text { will support the use of a tablet PC to } \\
\text { support teaching and learning activities }\end{array}$ & 0.800 \\
SI2 & $\begin{array}{l}\text { My family will allow my child to play } \\
\text { by using a tablet PC in his spare time }\end{array}$ & 0.769 \\
\hline
\end{tabular}

\section{Performance Expectancy}

Performance expectancy retains four items with factor loadings ranging from 0.502 to 0.853 . This construct has a Cronbach's alpha of 0.745 .

Table 2

EFA Result of Performance Expectancy

\begin{tabular}{lll}
\hline \multicolumn{1}{c}{ Items } & $\alpha=0.745$ \\
\hline PE2 & $\begin{array}{l}\text { Given a tablet PC, allowing my kid to } \\
\text { spend their leisure time playing at home }\end{array}$ & 0.853 \\
PE3 & $\begin{array}{l}\text { When my kid using a tablet PC, he/ } \\
\text { she will feel that the tablet PC will be } \\
\text { easier for him/her to play games }\end{array}$ & \\
\hline \multicolumn{3}{c}{$\alpha=0.821$} \\
\hline PE1 & $\begin{array}{l}\text { When my kid usingatabletPC, he/she will feel } \\
\text { that the tablet PC is useful for playing games }\end{array}$ & 0.818 \\
PE4 & $\begin{array}{l}\text { Using a tablet PC for studying, allowing my } \\
\text { kid to be more intelligent than his/her peers }\end{array}$ & 0.502 \\
\hline &
\end{tabular}

\section{Motivation}

Motivation forms three dimensions: firstly, encouraging behaviour. It has six items with factor loadings ranging from 0.405 and 0.856 and $a$ Cronbach's alpha score of 0.798 . Secondly, driving behaviour. This dimension keeps three items with factor loadings ranging from 0.666 to 0.857 and a Cronbach's alpha score of 0.753 . Thirdly, purpose of the behaviour. This dimension owns three items with factor loadings ranging from 0.729 to 0.915 and a Cronbach's alpha score of 0.804 .

Table 3

EFA Result of Motivation

\begin{tabular}{|c|c|c|}
\hline & Encouraging behaviour & $\alpha=0.798$ \\
\hline M2 & $\begin{array}{l}\text { Given a tablet PC of my kid will increase } \\
\text { in knowledge }\end{array}$ & 0.856 \\
\hline M3 & $\begin{array}{l}\text { Given a tablet PC my kid will increase his/ } \\
\text { her skills }\end{array}$ & 0.831 \\
\hline M1 & $\begin{array}{l}\text { Given a tablet PC my kid would try to find } \\
\text { new things }\end{array}$ & 0.672 \\
\hline M11 & $\begin{array}{l}\text { My kid will tell his/her friends about what } \\
\text { he/she learned/read/heard, when he/she } \\
\text { was playing with a tablet PC }\end{array}$ & 0.563 \\
\hline M10 & $\begin{array}{l}\text { My kid would rather play using a tablet } \\
\text { PC }\end{array}$ & 0.515 \\
\hline \multirow[t]{2}{*}{ M4 } & $\begin{array}{l}\text { Given a tablet PC will my kid be more } \\
\text { easily monitored/supervised activities }\end{array}$ & 0.405 \\
\hline & Driving behaviour & $\alpha=0.753$ \\
\hline M8 & $\begin{array}{l}\text { Given a tablet PC will my kid be able to } \\
\text { communicate with his/her peers (eg com- } \\
\text { munication via video calls) }\end{array}$ & 0.857 \\
\hline M9 & $\begin{array}{l}\text { Given a tablet PC, my son will be able to } \\
\text { get rest and relax }\end{array}$ & 0.845 \\
\hline \multirow[t]{3}{*}{ M12 } & $\begin{array}{l}\text { To tell his/her friends and family about } \\
\text { what he/she learned/ read/ heard using a } \\
\text { tablet PC }\end{array}$ & \\
\hline & $\begin{array}{l}\text { My son would tell me about what he } \\
\text { learned / read / heard, when he was play- } \\
\text { ing with a tablet PC }\end{array}$ & 0.666 \\
\hline & Purpose of the behaviour & $\alpha=0.804$ \\
\hline M6 & $\begin{array}{l}\text { Given a tablet PC, my kid will be able to } \\
\text { communicate with the family (eg commu- } \\
\text { nication via telephone) }\end{array}$ & 0.915 \\
\hline M5 & $\begin{array}{l}\text { Given a tablet PC, I will more easily } \\
\text { soothe my kid for a moment. So, I have } \\
\text { the time to work (eg household chores) }\end{array}$ & 0.882 \\
\hline M7 & $\begin{array}{l}\text { Given a tablet PC, my kid will be able to } \\
\text { communicate with his/her friends and } \\
\text { family (eg communication via video calls) }\end{array}$ & 0.729 \\
\hline
\end{tabular}

\section{Attitude Towards Adoption}

Attitude towards adoption is measured by two dimensions: the first dimension is 'the idea' and it has factor loadings ranging from 0.439 to 0.928 with 
a Cronbach's alpha score of 0.0838 . The second dimension is 'the action'. It has factor loadings of 0.807 and 0.823 with a Cronbach's alpha score of 0.685 .

Table 4

EFA Results of Attitude Towards a PC Tablet Adoption

\begin{tabular}{lll}
\hline \multicolumn{1}{c}{ The idea } & \multicolumn{1}{c}{$\alpha=0.838$} \\
\hline A2 & $\begin{array}{l}\text { Playing with using a tablet PC } \\
\text { during spare time is a good idea } \\
\text { for my kid }\end{array}$ & 0.928 \\
A1 $\quad \begin{array}{l}\text { My kid will be happier if accom- } \\
\text { panied his/her spare time by } \\
\text { playing a tablet PC }\end{array}$ & 0.772 \\
A5 $\quad \begin{array}{l}\text { Playing using a tablet PC is a } \\
\text { good idea for my kid }\end{array}$ & 0.703 \\
A3 $\quad \begin{array}{l}\text { Studying through a tablet PC is a } \\
\text { good idea for my kid's growth }\end{array}$ & 0.688 \\
A4 $\quad \begin{array}{l}\text { Studying through a tablet is a } \\
\text { wise thing to my kid's growth }\end{array}$ & 0.667 \\
A6 $\quad \begin{array}{l}\text { My kid dislikes the idea of using } \\
\text { a tablet PC }\end{array}$ & 0.439 \\
A6 & $\begin{array}{l}\text { The action } \\
\text { Given a tablet PC as a medium } \\
\text { of learning in school will make } \\
\text { my child interested in studying }\end{array}$ & 0.823 \\
A7 $\quad \begin{array}{l}\text { My kid will be happy to study by } \\
\text { using a tablet PC }\end{array}$ & 0.807 \\
\hline
\end{tabular}

\section{Intention to Use}

The five items of intention to use survive with a Cronbach's alpha score of 0.774 . This construct has factor loadings ranging from 0.651 to 0.774 .

Table 5

EFA Result of a Tablet PC Adoption Intention

\begin{tabular}{lll}
\hline & Items & $\alpha=0.774$ \\
\hline I1 & My kid intends to play using a tablet PC & 0.783 \\
I2 & $\begin{array}{l}\text { My kid intends to recommend to friends / } \\
\text { brothers to use a tablet PC }\end{array}$ & 0.764 \\
I5 & $\begin{array}{l}\text { My kid intends to use a tablet PC in the } \\
\text { future }\end{array}$ & 0.730 \\
I3 & $\begin{array}{l}\text { My kid intends to use a tablet PC in the } \\
\text { future }\end{array}$ & 0.706 \\
I4 $\quad \begin{array}{l}\text { My kid intends to visit his/her favorited } \\
\text { gaming application }\end{array}$ & 0.651 \\
\hline
\end{tabular}

\section{Hypotheses Testing}

The figure below is the result of structural equation model. This fitted model reaches a fitness with a probability score of 0.105 , CMIN/DF score of 1.274 , CFI score of 0.985 , and RMSEA score of 0.037 . Social influence retains two items including $\mathrm{SI} 3$ and SI4. Performance expectance retains two items: PE1 and PE3. Of three dimensions of motivation, one is dropped and another one is retaining. The remaining dimension of motivation has two items survive: M2 and M3. Furthermore, the exploratory factor analysis forms two dimensions of attitude: the idea dimension retains two items, A3 and $A 4$. The action dimension survives two items $A 7$ and A8). Of five items, two of them survive including 13 and 14.

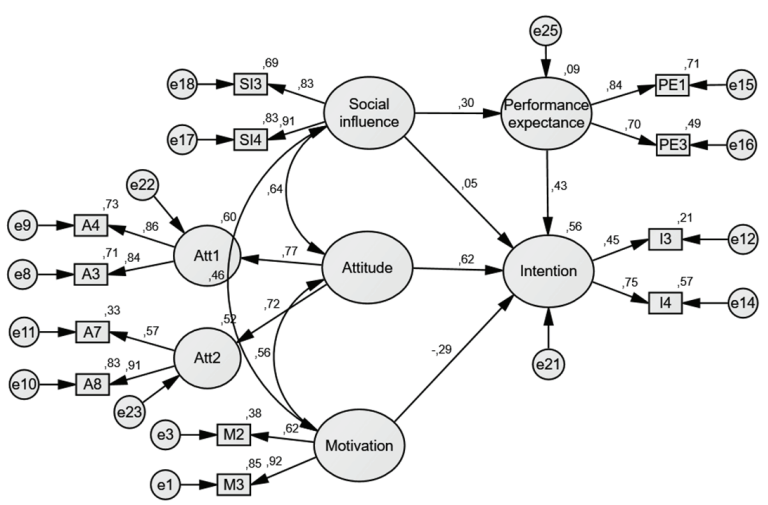

Figure 2. Structural model of the theoretical framework

The Table 6 below presents results of the hypotheses testing and says that $\mathrm{H} 1, \mathrm{H} 3$, and $\mathrm{H} 4$ were accepted whereas the $\mathrm{H} 2$ was rejected due to insignificance. $\mathrm{H} 5$ was significant with $\mathrm{C} . \mathrm{R}$. score of -2.107 . However, as the value was a negative, therefore it was this path was rejected.

Table 6

Summary of hypotheses testing

\begin{tabular}{|c|c|c|c|c|c|c|}
\hline & & & & C.R. & $\mathrm{P}$ & Results \\
\hline $\mathrm{H} 1$ & $\begin{array}{l}\text { Social } \\
\text { influence }\end{array}$ & $->$ & $\begin{array}{l}\text { Perfor- } \\
\text { mance } \\
\text { expect- } \\
\text { ance }\end{array}$ & 3.525 & $* * *$ & $\begin{array}{l}\text { Ac- } \\
\text { cepted }\end{array}$ \\
\hline $\mathrm{H} 2$ & $\begin{array}{l}\text { Social } \\
\text { influence }\end{array}$ & $\rightarrow$ & $\begin{array}{l}\text { Adoption } \\
\text { intention }\end{array}$ & 0.350 & 0.726 & $\begin{array}{l}\text { Re- } \\
\text { jected }\end{array}$ \\
\hline H3 & $\begin{array}{l}\text { Perfor- } \\
\text { mance } \\
\text { expect- } \\
\text { ance }\end{array}$ & $\rightarrow$ & $\begin{array}{l}\text { Adoption } \\
\text { intention }\end{array}$ & 3.068 & 0.002 & $\begin{array}{l}\text { Ac- } \\
\text { cepted }\end{array}$ \\
\hline $\mathrm{H} 4$ & Attitude & $\rightarrow$ & $\begin{array}{l}\text { Adoption } \\
\text { intention }\end{array}$ & 2.598 & 0.009 & $\begin{array}{l}\text { Ac- } \\
\text { cepted }\end{array}$ \\
\hline H5 & Motivation & $\rightarrow$ & $\begin{array}{l}\text { Adoption } \\
\text { intention }\end{array}$ & -2.107 & 0.035 & $\begin{array}{l}\text { Re- } \\
\text { jected }\end{array}$ \\
\hline
\end{tabular}

\section{Discussion}

The first hypothesis predicts the impact of social influence on performance expectation. Based on the calculation, the structural model showed social influence had a significant impact on performance expectation and it was supported by El-Gayar et al. (2011). This was to confirm $\mathrm{H} 1$ was accepted.

The second hypothesis predicts the impact of social influence on adoption intention. Apparently, the 
finding showed social influence had an insignificant impact on adoption intention. The result was different with the finding documented by Abu-Al-Aish and Love (2013), Astuti et al. (2016), El-Gayar et al. (2011), Foon (2014) and Moran et al. (2010).

The third hypothesis predicts the impact of performance expectation on adoption intention. This study found a significant impact on of performance expectation on adoption intention. This finding is supported by prior studies (Abu-Al-Aish \& Love, 2013; Astuti et al., 2016; El-Gayar et al., 2011; Magsamen-Conrad et al., 2015; Riaz \& Adnan, 2016; Thomas et al., 2013; Tosuntaş et al., 2015). Therefore, $\mathrm{H} 3$ was accepted. Kindergarten students with high performance expectancy would tend to adopt a tablet $\mathrm{PC}$ rather than the students with lower performance expectation.

The forth hypothesis predicts the impact of attitude towards a tablet PC adoption on adoption intention. Based on the finding, attitude had an insignificant impact on adoption intention. This finding was in line with prior studies (Aboelmaged \& Gebba, 2013; Foon, 2014; Park \& Pobil, 2013).

The last hypothesis predicts the impact of motivation on adoption intention. In the three models tested, the authors find that motivation has an insignificant impact on adoption intention. The result was contrast with the finding presented by existing studies conducted by Abduljalil and Zainuddin (2015), Saadé et al. (2008), and Yoo et al. (2012).

\section{CONCLUSION}

This study aimed to examine determinant factors that could predict a tablet PC adoption intention among kindergarten students. A projective technique was applied to obtain data by surveying parents of kindergarten students. Social influence, performance expectation, attitude, and motivation were selected as predictor variables. The findings were based on the structural model of the theoretical framework proposed. This current study found a significant impact of performance expectance and attitude towards adoption on adoption intention and social influence on performance expectance.

Projective technique does not record real voices from research subjects. What the subject feels, experiences, perceives, and thinks, are presented by a proxy. However, this technique helped the authors to explore the phenomenon. Further, convenience sampling method is also considered away from a representation of a population. While the techniques have some advantages to be applied in certain situations, but still they should be considered as a limitation of this study.

Considering benefits of a tablet PC for kindergarten students, in some schools, the use of a tablet PC is an obligation or just a recommendation. However, parents might not allow their kids to use a tablet PC for some reasons. In this case, social influence can be used for influencing one's attitude towards a tablet PC adoption and motivation to use instead of to develop one's adoption intention.

\section{REFERENCES}

Abduljalil, K. \& Zainuddin, Y. (2015). Intrinsic and extrinsic motivation as attitude factors towards adoption of accounting information system (AIS) in Libyan SMEs. International Journal of Academic Research in Accounting, Finance and Management Sciences, 5(1), 161-170.

Aboelmaged, M., \& Gebba, T. R. (2013). Mobile banking adoption: An examination of technology acceptance model and theory of planned behavior. International Journal of Business Research and Development (IJBRD), 2(1).

Abu-Al-Aish, A. \& Love, S. (2013). Factors influencing students' acceptance of m-learning: An investigation in higher education. The International Review of Research in Open and Distributed Learning, 14(5).

Akbar, Fatema. (2013). What affects students' acceptance and use of technology? (Bachelor), Carnegie Mellon University Qatar Campus, Qatar.

Astuti, N. C. , Zentira, Z., \& Dwiantoro, D. (2016). The drivers for acceptance table by postgraduate students and implications for eduation. Science International, 28(2), 1833-1839

Breckler, S. J., Olson, J., \& Wiggins, E. (2005). Social 
psychology alive. Cengage Learning.

Bruner, G.C., \& Kumar, A. (2005). Explaining consumer acceptance of handheld Internet devices. Journal of Business Research, 58(5), 553-558.

Chang, C-C., Liang, C., Yan, C-F., \& Tseng, J-S. (2013). The impact of college students' intrinsic and extrinsic motivation on continuance intention to use English Mobile Learning Systems. The Asia-Pacific Education Researcher, 22(2), 181-192.

Cuhadar, C. (2014). Information technologies preservice teachers' acceptance of tablet PCs as an innovative learning tool. Educational Sciences: Theory and Practice, 14(2), 741753.

Davis, F.D, Bagozzi, R. P., \& Warshaw, P. R. (1989). User acceptance of computer technology: A comparison of two theoretical models. Management science, 35(8), 982-1003.

Deursen, A. J. A. M. v., Allouch, S. b., \& Ruijter, L. P. (2016). Tablet use in primary education: Adoption hurdles and attitude determinants. Education and Information Technologies, 21(5), 971-990.

Dündar, H., \& Akçayır, M. (2014). Implementing tablet PCs in schools: Students' attitudes and opinions. Computers in Human Behavior, 32, 40-46.

El-Gayar, O.F., \& Moran, M. (2006). College students' acceptance of tablet PCs: an application of the UTAUT model. Dakota State University, 820.

El-Gayar, O.F., \& Moran, M. (2007). Examining students' acceptance of tablet PC using TAM. Issues in Information Systems, 8(1), 167-172.

El-Gayar, O.F., Moran, M., \& Hawkes, M. (2011). Students' acceptance of Tablet PCs and implications for educational institutions. Educational Technology \& Society, 14(2), 58-70.

Escobar-Rodríguez, T., Carvajal-Trujillo, E., \& Monge-Lozano, P. (2014). Factors that influence the perceived advantages and relevance of Facebook as a learning tool: An extension of the UTAUT. Australasian Journal of Educational Technology, 30(2), 136-151.

Fagan, M. H., Neill, S., \& Wooldridge, B. R. (2008). Exploring the intention to use computers: An empirical investigation of the role of intrinsic motivation, extrinsic motivation, and perceived ease of use. Journal of Computer Information Systems, 48(3), 31-37.

Foon, Y. S. (2014). A study on student behavioral intentions to use tablet personal computer as replacement of textbook. Journal of Human and Social Science Research, 2(2), 45-56.

Gilbert, A. D. (2015). An exploration of the use of and the attitudes toward technology in first-year instrumental music. (Doctoral), University of Nebraska, Nebraska.

Hair Jr., J. F., Black, W .C., Babin, B. J., Anderson, R. E., \& Tatham, R. L. (2006). Multivariate data analysis (6 ed.). New Jersey: PrenticeHall, Inc.

Hassan, M., Kouser, R., Abbas, S.S., \& Azeem, M. (2014). Consumer Attitudes and Intentions to Adopt Smartphone Apps: Case of Business Students. Pakistan Journal of Commerce and Social Sciences, 8(3), 763-779.

Hu, L., \& Bentler, P.M. (1999). Cutoff criteria for fit indexes in covariance structure analysis: Conventional criteria versus new alternatives. Structural Equation Modeling: A Multidisciplinary Journal, 6(1), 1-55.

Ifenthaler, D., \& Schweinbenz, V. (2013). The acceptance of Tablet-PCs in classroom instruction: The teachers' perspectives. Computers in Human Behavior, 29(3), 525534.

Kim, Y. H., Kim, D. J., \& Wachter, K. (2013). A study of mobile user engagement (MoEN): Engagement motivations, perceived value, satisfaction, and continued engagement intention. Decision Support Systems, 56, 361-370.

Lee, S.Yup. (2014). Examining the factors that influence early adopters' smartphone adoption: The case of college students. Telematics and Informatics, 31(2), 308-318.

Lee, S. (2013). An integrated adoption model for e-books in a mobile environment: Evidence from South Korea. Telematics and Informatics, 30(2), 165-176.

Li, S.S. (2014). Adoption of three new types of computers in Taiwan: Tablet PCs, netbooks, and smart phones. Computers in Human Behavior, 35, 243-251.

Lu, X., \& Viehland, D. (2008). Factors influencing the adoption of mobile learning. ACIS 2008 Proceedings, 56. 
Magsamen-Conrad, K., Upadhyaya, S., Joa, C.Y., \& Dowd, J. (2015). Bridging the divide: Using UTAUT to predict multigenerational tablet adoption practices. Computers in Human Behavior, 50, 186-196.

Mäkitalo-Siegl, K. (2013). Using tablet PCs in teaching and learning. Paper presented at the The European Conference on Educational Research 2013, Istanbul http://www.eeraecer.de/ecer-programmes/conference/8/ contribution/22585/

Mirusmonov, M., \& Kim, C. (2013, June 18-22, 2013). Intrinsic and extrinsic motivation impact on mobile cloud computing continuance intention. Paper presented at the Pacific Asia Conference on Information Systems (PACIS), Jeju Island.

Moran, M., Hawkes, M., \& El Gayar, O. (2010). Tablet personal computer integration in higher education: Applying the unified theory of acceptance and use technology model to understand supporting factors. Journal of Educational Computing Research, 42(1), 79-101.

O'Regan, M., \& Chang, H. (2015). Smartphone adoption amongst Chinese youth during leisure-based tourism: Challenges and opportunities. Journal of China Tourism Research, 11(3), 238-254.

Park, E., \& Pobil, A.P. del. (2013). Technology acceptance model for the use of tablet PCs. Wireless Personal Communications, 73(4), 1561-1572.

Rashotte, L. (2007). Social influence. The blackwell Encyclopedia of Social Psychology, 9, 562563.

Riaz, A., \& Adnan, A. (2016). Acceptance of tablet apps for e-learning by senior users: A test of unified theory of acceptance and use of technology. Paper presented at the 8th PanCommonwealth Forum on Open Learning (PCF8)

Kuala Lumpur. http://oasis.col.org/ bitstream/handle/11599/2537/ PDF? sequence=1\&isAllowed=y

Saadé, R. G., Tan, W., \& Nebebe, F. (2008). Impact of motivation on intentions in online learning: Canada vs China. Paper presented at the The Journal of Issues in Informing Science and Information Technology. http://proceedings.informingscience.org/ InSITE2008/IISITv5p137-147Saade463.pdf

Schermelleh-Engel, K., Moosbrugger, H., \& Müller, H. (2003). Evaluating the fit of structural equation models: Tests of significance and descriptive goodness-of-fit measures. Methods of Psychological Research Online, 8(2), 23-74.

Steinman, R.B. (2008, October 30th \& 31 th, 2008 ). Projective techniques in consumer research. Paper presented at the Northeastern Association of Business, Economics, and Technology (NABET) 30th Annual Meeting, Pennsylvania.

Sung, H., Jeong, D., Jeong, Y., \& Shin, J. (2015). The relationship among self-efficacy, social influence, performance expectancy, effort expectancy, and behavioral intention in mobile learning service. International Journal of u-and e-Service, Science and Technology, 8(9), 197-206.

Sung, Y-T., Chang, K-E., \& Liu, T-C. (2016). The effects of integrating mobile devices with teaching and learning on students' learning performance: A meta-analysis and research synthesis. Computers \& Education, 94, 252275.

Tabachnick, B. G., \& Fidell, L. S. (2007). Using multivariate statistics (5 ed.). Boston Pearson/ Allyn \& Bacon.

Teo, Thompson S. H., \& Pok, Siau Heong. (2003). Adoption of WAP-enabled mobile phones among Internet users. Omega, 31(6), 483498.

Thomas, T.D., Singh, L., \& Gaffar, K. (2013). The utility of the UTAUT model in explaining mobile learning adoption in higher education in Guyana. International Journal of Education and Development using Information and Communication Technology, 9(3), 71.

Tosuntaş, Ş. B., Karadağ, E., \& Orhan, S. (2015). The factors affecting acceptance and use of interactive whiteboard within the scope of FATIH project: A structural equation model based on the Unified Theory of acceptance and use of technology. Computers \& Education, 81, 169-178.

Vanwelsenaers, M. (2012). Students using their own technology device in the classroom: Can "BYOD" increase motivation and learning. 
(Master), Northern Michigan University, Michigan

Venkatesh, V., Morris, M.G., Davis, Gordon B., \& Davis, Fred D. (2003). User acceptance of information technology: Toward a unified view. MIS quarterly, 27(3), 425-478.

Venkatesh, V., Thong, J. Y. L., \& Xu, X. (2012). Consumer acceptance and use of information technology: extending the unified theory of acceptance and use of technology. MIS quarterly, 36(1), 157-178.

Wu, J., Wang, S., \& Lin, L. (2007). Mobile computing acceptance factors in the healthcare industry:
A structural equation model. International Journal of Medical Informatics, 76(1), 66-77.

Yang, K., \& Forney, J.C. (2013). The moderating role of consumer technology anxiety in mobile shopping adoption: differential effects of facilitating conditions and social influences. Journal of Electronic Commerce Research, 14(4), 334.

Yoo, S. J., Han, S-H., \& Huang, W. (2012). The roles of intrinsic motivators and extrinsic motivators in promoting e-learning in the workplace: A case from South Korea. Computers in Human Behavior, 28(3), 942-950. 